\title{
Theoretical Analysis of the Potential of Silver Carp Hypophthalmichthys Molitrix in the Control of Water Blooming by Different Species of Cyanobacteria
}

\author{
Igor G. Prokopkin ${ }^{\text {a*}}$, Vladimir I. Kolmakov', \\ Vladimir G. Gubanov $^{\text {a }}$, Michail I. Gladyshev, ${ }^{\mathrm{a}, \mathrm{b}}$ \\ ${ }^{a}$ Institute of Biophysics of Siberian Branch of Russian Academy of Sciences, \\ Akademgorodok, Krasnoyarsk, 660036 Russia \\ ${ }^{b}$ Siberian Federal University \\ 79 Svobodny, Krasnoyarsk, 660041 Russia ${ }^{1}$
}

Received 7.12.2009, received in revised form 14.12.2009, accepted 21.12.2009

The possibility to use silver carp (Hypophthalmichthys molitrix) in the control of water blooming by cyanobacteria is theoretically analyzed. To attain this goal the dynamic model has been developed, describing communities of two species of cyanobacteria: Anabaena flos-aquae and Microcystis aeruginosa, taking into account direct influence of silver carp on cyanobacteria growth-stimulation of cyanobacteria growth rate and cyanobacteria digestion in fish gut. The calculation results have shown that silver carp influences oppositely the formation of blooming by cyanobacteria species simulated. Reservoir stocking with silver carp inhibits the development of Anabaena flos-aquae species. The development of Microcystis aeruginosa is not constrained by silver carp. Forming blooming outbreaks by this species is possible even with increasing stocking. One of the possible reasons may be the fact that the Microcystis aeruginosa growth is stimulated after passing through fish gut. Therefore, when planning biomanipulations using silver carp it is necessary to take into consideration the relationship between fish and the different species of cyanobacteria. The success of such manipulations depends on what species of cyanobacteria are dominant in the ecosystem in the blooming period.

Keywords: simulation model; biomanipulation; silver carp; cyanobacteria; viable gut passage

\section{Introduction}

Searching the way to prevent reservoirs from blooming by cyanobacteria has been one of the principal objectives of the modern hydrobiology during the last decades. A great number of different physical, chemical and biological methods to prevent blooming have been developed since, with the method of foodweb manipulation occupying a special place. This approach is the most ecologically sound management strategy (Datta, Jana, 1998). In most cases biomanipulation led to an improvement in the water quality (e.g. Annadotter et al., 1999; Gulati, van Donk, 2002).

The 'classical' approach in biomanipulation is the increase of carnivorous fish biomass and/ or decrease of planktivorous fish biomass (e.g. Lammens, 1999; Drenner, Hambright, 2002), which leads to the increase of zooplankton biomass and reduction of cyanobacteria concentration.

* Corresponding author E-mail address: prokop@ibp.ru

(C) Siberian Federal University. All rights reserved 
The principles and applications of this food-web manipulation were mainly developed in temperate regions (Gophen, 1990). For tropical and subtropical freshwater ecosystems an alternative biomanipulation approach was developed, based on the direct control of undesirable phytoplankton by filter feeding planktivorous fish (e.g. Crisman, Beaver, 1990; Miura, 1990). One of the fish, widely used in this biomanipulation, is the silver carp Hypophthalmichthys molitrix Val. (e.g. Starling, 1993; Datta, Jana, 1998).

This species naturally occurs in China. An adult silver carp mainly consumes phytoplankton and detritus. For this reason, it has been used in water management to improve water quality, and was introduced in waters of Asia, Europe and the United States (e.g. Herodek et al., 1989).

To evaluate the potential of silver carp in the control of blooming, many experimental works have been carried on worldwide in tropical and temperate regions (e.g. Miura, 1990). Although different experiments demonstrated that silver carp controlled phytoplankton abundance Starling, Rocha, 1990), some of them led to the absence of the desired effect (e.g. Radke, Kahl, 2002). In addition, some ponds stocked with silver carp are reported to show an increase in the phytoplankton biomass (Burke et al., 1986).

One of the explanations of such results may be the fact that silver carp only partly assimilates phytoplankton. The part of microalgae and cyanobacteria remains viable after the passage through the intestinal tract of fish and, moreover, some species of cyanobacteria after passing through fish gut increase the intensity of photosynthesis and growth rate (Kolmakov et al., 2006). The stimulation of cyanobacteria growth by silver carp may be one of the reasons of forming and maintaining water blooming. As a result, the potential of silver carp for the direct control of undesirable phytoplankton is still an open question.
In accordance with the above considerations, the main purpose of this study is to estimate silver carp influence on the growth of cyanobacteria that form reservoir blooming, by methods of mathematical simulation. There is no reported evidence of using methods of mathematical simulation to study the potential of silver carp for control of undesirable phytoplankton.

For this purpose, we have chosen two typical species of cyanobacteria - Anabaena flos-aquae (Lyngb.) Breb. and Microcystis aeruginosa Kutz. These species are usually considered among the main contributors to water blooming. In reservoirs, these species form peaks of biomass in different periods of summer because their optimal growth temperatures are significantly different. Moreover, laboratory experiments (Kolmakov et. al., 2006) showed that these species of cyanobacteria respond differently to passing through silver carp gut. Anabaena flos-aquae is almost completely assimilated by fish while Microcystis aeruginosa is far less assimilated and even acquires temporary growth stimulation after passing through fish gut. The choice of these species of cyanobacteria as simulation objects allows one to consider different responses of cyanobacteria to reservoir stocking with silver carp and to estimate the effect of reservoir stocking with silver carp on the formation of water blooming in different summer periods.

\section{Materials and Methods: Model description}

\section{Model structure}

The model describes the dynamics of mineral phosphorus (S) and biomass of the two species of cyanobacteria in an abstract reservoir. One of the cyanobacteria species is Anabaena flos-aquae $\left(\mathrm{X}^{1}\right)$, which usually forms the blooming peak in early summer. The other species is Microcystis aeruginosa $\left(\mathrm{X}^{2}\right)$, which forms blooming in the middle or late summer. 
The silver carp (Hypophthalmichthys molitrix) swallows cyanobacteria when eating. As a result, part of cyanobacteria is assimilated when passing through the gut of silver carp. The living part of cyanobacteria can increase the growth rate after gut passage (stimulated state). The consumption of cyanobacteria by zooplankton is not taken into account in the model.

\section{State equations}

At the beginning of the calculation, the biomasses of cyanobacteria have the minimum values, which correspond to the spring start conditions. For simplification, it is assumed that at this moment none of cyanobacteria are stimulated by passing through the gut of silver carp.

During the calculation part of cyanobacteria are swallowed by fish. As a result, the biomass of each species of cyanobacteria is divided into 2 subgroups:

$$
X^{i}=X_{n . s .}^{i}+X_{s .}^{i},
$$

where $X_{s .}^{i}$ and $X_{n . s .}^{i}$ are the biomass of cyanobacteria $\left(\mathrm{mg} \cdot \mathrm{L}^{-1}\right)$, whose growth is respectively stimulated and not stimulated (or stimulation is finished, see below) by passing through the gut ( $\mathrm{i}=1$ for Anabaena flos-aquae, $\mathrm{i}$ $=2$ for Microcystis aeruginosa).

The dynamics of the subgroups $X_{s .}^{i}$ and $X_{n . s .}^{i}$. $\left(\mathrm{mg} \cdot \mathrm{L}^{-1}\right)$ is defined as:

$$
\begin{aligned}
& d X_{n . s .}^{i} / d t=\mu_{n . s .}^{i} \cdot X_{n . s .}^{i}-\gamma^{i} \cdot X_{n . s .}^{i}- \\
& -f \cdot X_{n . s .}^{i}-D \cdot X_{n . s .}^{i}, \\
& d X_{s .}^{i} / d t=\mu_{s .}^{i} \cdot X_{s .}^{i}-\gamma^{i} \cdot X_{s .}^{i}+ \\
& +f \cdot\left(1-u^{i}\right) \cdot\left(X_{n . s .}^{i}+X_{s .}^{i}\right)_{-} \\
& -f \cdot X_{s .}^{i}-D \cdot X_{s .}^{i},
\end{aligned}
$$

where $\mu$ is the specific growth rate $\left(\mathrm{h}^{-1}\right)$ $\left(\mu_{s .}^{i} \geq \mu_{n . s .}^{i}\right), \gamma$ is the specific death rate $\left(\mathrm{h}^{-1}\right)$, $f$ is the filtration rate of the population of silver carp $\left(\mathrm{h}^{-1}\right), D$ is the specific outflow rate $\left(\mathrm{h}^{-1}\right), u-$ coefficient of cyanobacteria assimilation by silver carp, $t$ - the current simulated time.

The processes of growth and mortality are calculated for each species of cyanobacteria. Specific growth rate of cyanobacteria $\mu$ depends on the concentration of mineral phosphorus, water temperature and light intensity. Specific death rate $\gamma$ is constant during the calculations (see below). Cyanobacteria can be removed from the reservoir by possible outflows (rivers, brooks etc.) - hence the terms $D \cdot X_{n . s .}^{i}$ and $D \cdot X_{s}^{i}$ in the equations. For simplification of the model, the entry of cyanobacteria to the reservoir with different inflows is not taken into account, because the biomass of cyanobacteria in inflows is usually not essential in comparison with the biomass in the reservoir.

The terms of equations $f \cdot X_{n . s .}^{i}$ and $f \cdot X_{s}^{i}$. describe the swallowing of cyanobacteria by fish with the filtration rate $f$. Part of swallowed biomass is assimilated with the coefficient $u$. Another part of swallowed cyanobacteria becomes stimulated and returns from the fish gut to subgroups $X_{s .}^{i}-$ the term of equation $f \cdot\left(1-u^{i}\right) \cdot\left(X_{n . s .}^{i}+X_{s .}^{i}\right)$.

In this case we neglect the time of passing through the gut of silver carp because it equals a few hours, in contrast to the time of stimulation, which equals several days.

As the stimulation of cyanobacterial growth by fish is time-limited (Kolmakov et al., 2006), it is necessary to transfer the part of cyanobacteria whose growth stimulation has stopped from subgroup $X_{s}^{i}$ to subgroup $X_{n . s .}^{i}$. Function $H^{i}(t)$ describing the quantity of cyanobacteria whose growth stimulation has stopped is written as:

$$
H^{i}(t)=\left\{\begin{array}{c}
0, \quad \text { if } \quad t<\xi \\
f \cdot\left(1-u^{i}\right) \cdot\left(X_{n . s .}^{i}(t-\xi)+X_{s .}^{i}(t-\xi)\right) \cdot e^{\int_{t-\xi}^{t}\left(u_{s .}^{i}(\tau)-\gamma^{i}-f-D\right) d \tau}, \quad \text { if } \quad t>=\xi
\end{array}\right.
$$


where $\xi$ is the time frame of growth stimulation effect (d); $t$ is the current simulated time.

Thus, at each step we calculated the biomass of $X_{n . s .}^{i}$ and $X_{s .}^{i}$ subgroups, the value of $H^{i}$ function and re-assigned the values of variables:

$$
X_{n . s .}^{i}=X_{n . s .}^{i}+H^{i}, X_{s .}^{i}=X_{s .}^{i}-H^{i} .
$$

Dynamics of mineral phosphorus $S\left(\mathrm{mg} \cdot \mathrm{L}^{-1}\right)$ is written as:

$$
\begin{aligned}
& d S / d t=S_{i n}- \\
& -\sum_{i=1}^{2} \frac{\left(\mu_{n . s .}^{i} \cdot X_{n . s .}^{i}+\mu_{s .}^{i} \cdot X_{s .}^{i}\right)}{Y^{i}}-D \cdot S,
\end{aligned}
$$

where, $S_{\text {in }}$ is the input of mineral phosphorus $\left(\mathrm{mg} \cdot \mathrm{L}^{-1} \cdot \mathrm{h}^{-1}\right), Y$ is the coefficient of cyanobacterial yield on mineral phosphorus ( $\mathrm{mg} \cdot \mathrm{mg}^{-1}$ ).

The dynamics of mineral phosphorus in the model is formed by the input of mineral phosphorous $S_{i n}$, the consumption by algae and the removal from the reservoir by outflow. To simplify the model, the input of mineral phosphorus is the sum of all sources, without dividing into external loading and recycling from zooplankton, fish and other possible sources. The input value of the mineral phosphorus is chosen such that in calculation without silver carp: a) the biomass of cyanobacteria reaches the real values, b) dates of the blooming peaks of a reservoir are correct and correspond to real natural observations.

Therefore, we now confine our attention to the method of a biomanipulation as an important component of an integrated approach to counteract cyanobacteria blooms, especially in lakes where nutrient inputs cannot be reduced sufficiently (Xie, Liu, 2001).

\section{Rate equations and constants}

\subsection{Specific growth rate of cyanobacteria}

The specific growth rate for $X_{n . s .}^{i}$ will be defined by multiplicative dependence on limiting factors (Gubanov et al., 1996):

$$
\mu_{n . s .}^{i}=\mu_{X \max }^{i} \cdot F(S) \cdot F(T) \cdot F(E),
$$

where $\mu_{X \max }^{i}$ is the maximum specific growth rate of cyanobacteria $\left(\mathrm{h}^{-1}\right)$,

$$
F(S)=\frac{S}{K_{S}^{i}+S},
$$

is the Monod function defining the dependence of cyanobacteria specific growth rate upon the substrate (mineral phosphorus) concentration, where $K_{S}^{i}$ is the half-saturation constant on mineral phosphorus $\left(\mathrm{mg} \cdot \mathrm{L}^{-1}\right)$,

$$
F(T)=\exp \left[-\left(\frac{T-T_{0}^{i}}{q^{i}}\right)^{2}\right],
$$

is the dependence of cyanobacteria specific growth rate upon water temperature, where $T$ is water temperature $\left({ }^{\circ} \mathrm{C}\right) ; T_{0}^{i}$ is water temperature optimal for cyanobacterial growth $\left({ }^{\circ} \mathrm{C}\right) ; q^{i}$ is thermal dispersion $\left({ }^{\circ} \mathrm{C}\right)$.

Term $F(E)$ defining the dependence of cyanobacteria specific growth rate upon irradiance and thickness of water layer $h(\mathrm{~m})$ will be written on the basis of Bouguer-Lambert law in the following way:

$$
\begin{aligned}
& F(E)=\frac{E_{h}}{E_{h}+e+r E_{h}^{2}}, \\
& E_{h}=\frac{E_{0}\left\{1-\exp \left[-h\left(a+b X_{t o t}\right)\right]\right\}}{h\left(a+b X_{t o t}\right)},
\end{aligned}
$$

where $E_{h}$ is the average irradiance on the water layer thickness $h\left(\mathrm{~W} \cdot \mathrm{m}^{-2}\right) ; E_{0}$ is the surface irradiance $\left(\mathrm{W} \cdot \mathrm{m}^{-2}\right) ; e$ is the half-saturation constant on light $\left(\mathrm{W} \cdot \mathrm{m}^{-2}\right) ; r$ is the coefficient of cyanobacteria growth rate inhibition by light $\left(\mathrm{m}^{2} \cdot \mathrm{W}^{-1}\right) ; a, b$ are the coefficients of light absorption by water $\left(\mathrm{m}^{-1}\right)$ and cyanobacterial biomass unit $\left(\mathrm{L} \cdot \mathrm{mg}^{-1} \cdot \mathrm{m}^{-1}\right), X_{t o t}$ is the sum of biomasses of Anabaena flos-aquae and Microcystis aeruginosa.

The specific growth rate for $X_{S}^{i}$ will be calculated according to the Liebig principle for systems with limiting factors (Abrosov et al., 1982) as follows: 


$$
\mu_{s .}^{i}=\min \left\{k^{i} \cdot \mu_{n . s .}^{i}, \mu_{X \max }^{i}\right\}
$$

where $k^{i}$ is the coefficient of growth rate increase after cyanobacteria passing through fish gut.

\subsection{Specific death rate of cyanobacteria}

Traditionally, the specific death rate of algae has a simple form - either a constant (Prokopkin et. al., 2006) or a function of water temperature (Montealegre et al., 1995; Omlin et al., 2001).

In this model, the specific death rate of cyanobacteria is constant and equal to $8 \%$ of the maximum specific growth rate (Gubanov et al., 1996) (Table 1).

\subsection{Specific outflow rate}

To simplify the model, we assume that during the time of calculation the specific outflow rate is also constant: $D=0.00026 \mathrm{~h}^{-1}$ (Table 2).

\subsection{Filtration rate of silver carp}

According to the data of Antalfi, Tolg (1971), the filtration rate of a silver carp equals $128 \mathrm{~mL} \cdot \mathrm{h}^{-1} \cdot \mathrm{g}^{-1}$. Spittler (1981) reported the filtration rate for fish weighing $1.3 \pm 0.2 \mathrm{~g}$ to be $241 \pm 139 \mathrm{~mL} \cdot \mathrm{h}^{-1}$. Opuszynski et. al. (1991) reported that the filtration rate of bighead carp (a closely related species) ranged from 185 to $256 \mathrm{~mL} \cdot \mathrm{h}^{-1} \cdot \mathrm{g}^{-1}$ and was higher for larger fish. According to these data, in our model

Table 1. Summary of main parameters of cyanobacteria species

\begin{tabular}{|c|c|c|c|}
\hline \multirow{2}{*}{ Symbol } & \multirow{2}{*}{ Definition } & \multicolumn{2}{|c|}{ Value (units) } \\
\hline & & Anabaena flos-aquae & Microcystis aeruginosa \\
\hline$\mu_{X \max }^{i}$ & maximum specific growth rate & $0.042\left(\mathrm{~h}^{-1}\right)$ & $0.042\left(\mathrm{~h}^{-1}\right)$ \\
\hline$K_{S}^{i}$ & half-saturation constant on mineral phosphorus & $0.05\left(\mathrm{mgP} \cdot \mathrm{L}^{-1}\right)$ & $0.05\left(\mathrm{mgP} \cdot \mathrm{L}^{-1}\right)$ \\
\hline$T_{0}^{i}$ & $\begin{array}{l}\text { water temperature optimal for cyanobacteria } \\
\text { growth }\end{array}$ & $18\left({ }^{\circ} \mathrm{C}\right)$ & $25\left({ }^{\circ} \mathrm{C}\right)$ \\
\hline$q^{i}$ & thermal dispersion & $6\left({ }^{\circ} \mathrm{C}\right)$ & $6\left({ }^{\circ} \mathrm{C}\right)$ \\
\hline$\gamma^{\mathrm{i}}$ & specific death rate & $0.0033\left(h^{-1}\right)$ & $0.0033\left(\mathrm{~h}^{-1}\right)$ \\
\hline$Y^{i}$ & $\begin{array}{l}\text { coefficient of cyanobacterial yield on mineral } \\
\text { phosphorus }\end{array}$ & $800\left(\mathrm{mg} \cdot \mathrm{mg}^{-1}\right)$ & $800\left(\mathrm{mg} \cdot \mathrm{mg}^{-1}\right)$ \\
\hline$u^{i}$ & $\begin{array}{l}\text { coefficient of assimilation cyanobacteria by silver } \\
\text { carp }\end{array}$ & 0.95 & 0.05 \\
\hline$k^{i}$ & $\begin{array}{l}\text { coefficient of growth rate increase after } \\
\text { cyanobacteria passing through fishes intestine }\end{array}$ & 1 & 3 \\
\hline
\end{tabular}

Table 2. Additional summary of model parameters

\begin{tabular}{|c|c|c|}
\hline Symbol & Definition & Value (units) \\
\hline$e$ & half-saturation constant on light & $25\left(\mathrm{~W} \cdot \mathrm{m}^{-2}\right)$ \\
\hline$r$ & $\begin{array}{l}\text { coefficient of cyanobacteria growth rate inhibition } \\
\text { by light }\end{array}$ & $0.001\left(\mathrm{~m}^{2} \cdot \mathrm{W}^{-1}\right)$ \\
\hline$a$ & coefficient of light absorption by water & $1\left(\mathrm{~m}^{-1}\right)$ \\
\hline$b$ & coefficient of light absorption by cyanobacterial biomass unit & $0.01\left(\mathrm{~L} \cdot \mathrm{mg}^{-1} \cdot \mathrm{m}^{-1}\right)$ \\
\hline$S_{\text {in }}$ & phosphorus input concentration & $0.00013\left(\mathrm{mg} \cdot \mathrm{L}^{-1} \cdot \mathrm{h}^{-1}\right)$ \\
\hline$D$ & specific outflow rate & $0.00026\left(\mathrm{~h}^{-1}\right)$ \\
\hline$h$ & thickness of water layer & $2(\mathrm{~m})$ \\
\hline$\xi$ & time frame of growth stimulation action & 7 (day) \\
\hline
\end{tabular}


the filtration rate of the silver carp amounts to $200 \mathrm{~mL} \cdot \mathrm{h}^{-1} \cdot \mathrm{g}^{-1}$.

The values of fish stocking vary widely in different experiments. For example, Domaizon and Devaux (1999) had five levels of stocking with silver carp: $0,4,8,16,36 \mathrm{~g} \cdot \mathrm{m}^{-3}$. In other investigations the stocking equals to $41 \mathrm{~g} \cdot \mathrm{m}^{-3}$ (Starling, 1993), 10-54 $\mathrm{g} \cdot \mathrm{m}^{-3}$ and 3-15 $\mathrm{g} \cdot \mathrm{m}^{-3}$ (Fukushima et. al., 1999). According to these data, in this model the biomass of silver carp has four basic levels: $10,20,50,100 \mathrm{~g} \cdot \mathrm{m}^{-3}$.

Thus, the filtration rate of the population of silver carp $f$ equals $0.002,0.004,0.01,0.02 \mathrm{~h}^{-1}$. For simplification of the model, the filtration rate is constant during the calculations. Of course, this is unrealistic, because the biomass of fish can change during summer and filtration rate of fish is influenced by environmental conditions as well. However, this assumption makes the comparisons of calculations easier.

\section{Model parameters and constants}

The symbols, definitions, units and values of all parameters are presented in Tables 1, 2 .

The values of the parameters describing growth and mortality of cyanobacteria are obtained by revising the references (Robarts, Zohary, 1987; Lee, Rhee, 1999; Gubanov et al., 1996; Bolsunovsky, 1999). The values of the parameters describing the effect of silver carp on cyanobacteria are obtained from Kolmakov et al. (2006). Other parameters, for example $D$ or $S_{i n}$, have such values that in calculations neglecting the influence of fish on cyanobacterial growth there are two peaks (in early and late summer) of water blooming with real biomass of algae.

The water temperature changes from $10{ }^{\circ} \mathrm{C}$ to $25^{\circ} \mathrm{C}$ during calculations, which is usual for temperate regions. The value of surface irradiance has a seasonal and diurnal rhythm: $E_{0}$ has maximum value at zenith (for example,
$370 \mathrm{~W} \cdot \mathrm{m}^{-2} \mathrm{PAR}$ in July) and minimum value $\left(0.5 \mathrm{~W} \cdot \mathrm{m}^{-2} \mathrm{PAR}\right)$ at night.

\section{Initial conditions}

The calculations were made from May, 1 to October, 1. The growth of Anabaena flos-aquae $\left(X_{0}^{1}=0.5 \mathrm{mg} \cdot \mathrm{L}^{-1}\right)$ and Microcystis aeruginosa $\left(X_{0}^{2}=0.5 \mathrm{mg} \cdot \mathrm{L}^{-1}\right)$ began on first day.

\section{Results}

The biomass dynamics of two cyanobacteria species without the influence of silver carp is given in Fig. 1. As Anabaena flos-aquae has value of $T_{0}^{1}$ close to the value of water temperature in early summer, the first peak of water blooming is formed by this species. The peak biomass of Anabaena flos-aquae reaches $\approx 50 \mathrm{mg} \cdot \mathrm{L}^{-1}$. The second peak of blooming is caused by Microcystis aeruginosa and reaches approximately $25 \mathrm{mg} \cdot \mathrm{L}^{-1}$ during August.

Stocking reservoir with silver carp even in small amounts $10 \mathrm{~g} \cdot \mathrm{m}^{-3}$ results in significant changes in the dynamics of cyanobacteria biomass (Fig. 2a). The maximum biomass of Anabaena flos-aquae decreases more than two times, with the peak of blooming caused by Microcystis aeruginosa becoming higher and wider.

The introduction of $20 \mathrm{~g} \cdot \mathrm{m}^{-3}$ of silver carp leads to still greater deformations of blooming peaks. Anabaena flos-aquae almost completely disappears from the system, while Microcystis aeruginosa bloom occurs during the whole summer (Fig. 2b). Increasing silver carp stocking up to $50 \mathrm{~g} \cdot \mathrm{m}^{-3}$ results in the complete disappearance of Anabaena flos-aquae (Fig. 2c).

\section{Discussion}

Our calculations show different responses of Anabaena flos-aquae and Microcystis aeruginosa to increasing levels of silver carp stocking. There is a general tendency for the increase of fish biomass to result in the decrease of Anabaena 


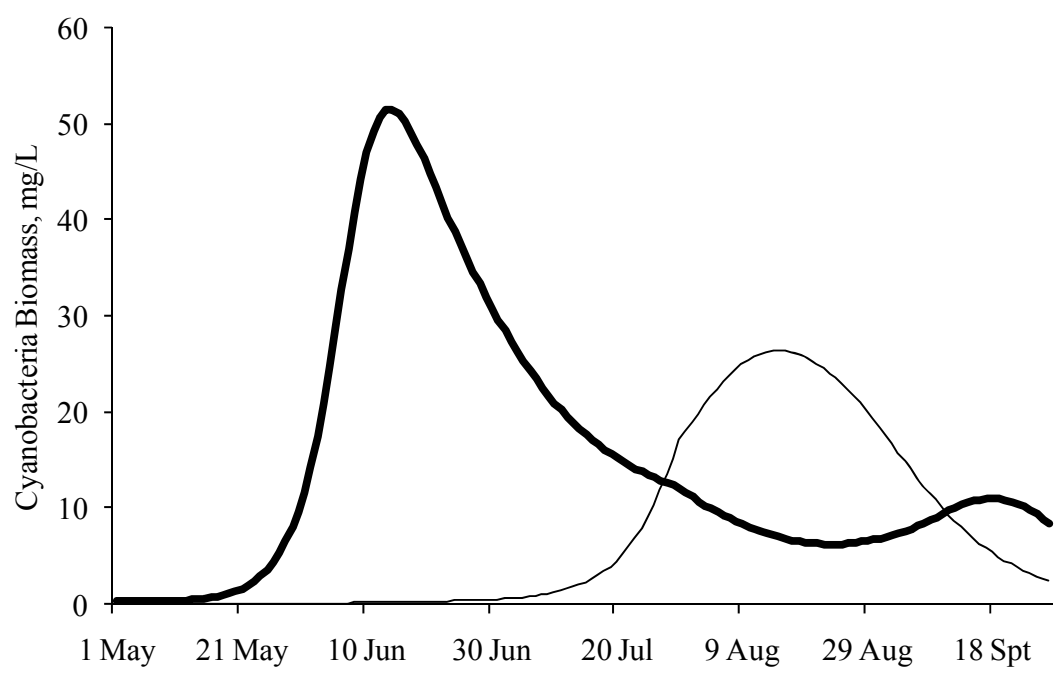

Fig. 1. Model calculations of biomass of cyanobacteria in the system without silver carp: the thick line - Anabaena flos-aquae, the thin line-Microcystis aeruginosa

flos-aquae biomass and increase of blooming peak caused by Microcystis aeruginosa (Fig. 2). The response of Anabaena flos-aquae to stocking with silver carp is thus negative. Increasing Microcystis aeruginosa biomass may be thought to be a positive response or a peculiarity of the model, which considers the dynamics of only two species of phytoplankton and, when one of them disappears, the other develops rapidly in the simulated system. However, it can be stated that at least Microcystis aeruginosa development is not constrained by silver carp and the ecosystem can have bloom outbreaks by this species after stocking.

Since the system simulated has a much simpler structure than natural ecosystems, it would not be quite correct to compare our results with those obtained in nature or laboratory experiments. Nevertheless, there are literature data showing that natural ecosystems can experience Microcystis blooms even after biomanipulations (Xie, Liu, 2001), which has a qualitative similarity with the results of our calculations regarding this species of cyanobacteria (see above). Xie and Liu (2001) also showed that in Lake Donghu (China) the recurrence of blooms could be prevented if the biomass of silver plus bighead carp would be held at or above $\approx 50 \mathrm{~g} \cdot \mathrm{m}^{-3}$. In our simulations, the introduction of 50 and more $\mathrm{g} \cdot \mathrm{m}^{-3}$ of silver carp also prevents Anabaena flos-aquae blooming.

One of the explanations of the fact that Anabaena flos-aquae is inhibited by silver carp may be a high assimilation of this species by the fish. The laboratory experiments (Kolmakov et. al., 2006) have shown that silver carp assimilates up to $95 \%$ of the Anabaena flos-aquae biomass and it is this value that the parameter $u^{l}$ takes up in the model under consideration (Table 1). However, even with $u^{l}=0.05$, one can observe a decrease of biomass of these cyanobacteria with increasing stocking amount, which is similar to the tendency discussed above (cf. Fig. 2 and Fig. 3). It is obvious that this species of cyanobacteria has such growth characteristics that a slight trophic pressure by silver carp can control its blooming.

All calculations show that increasing stocking amount does not result in a significant decrease of Microcystis aeruginosa biomass (Fig. 2, 3). According to the results of laboratory experiments (Kolmakov et. al., 2006) this species temporarily increases its growth rate 2-3 times 

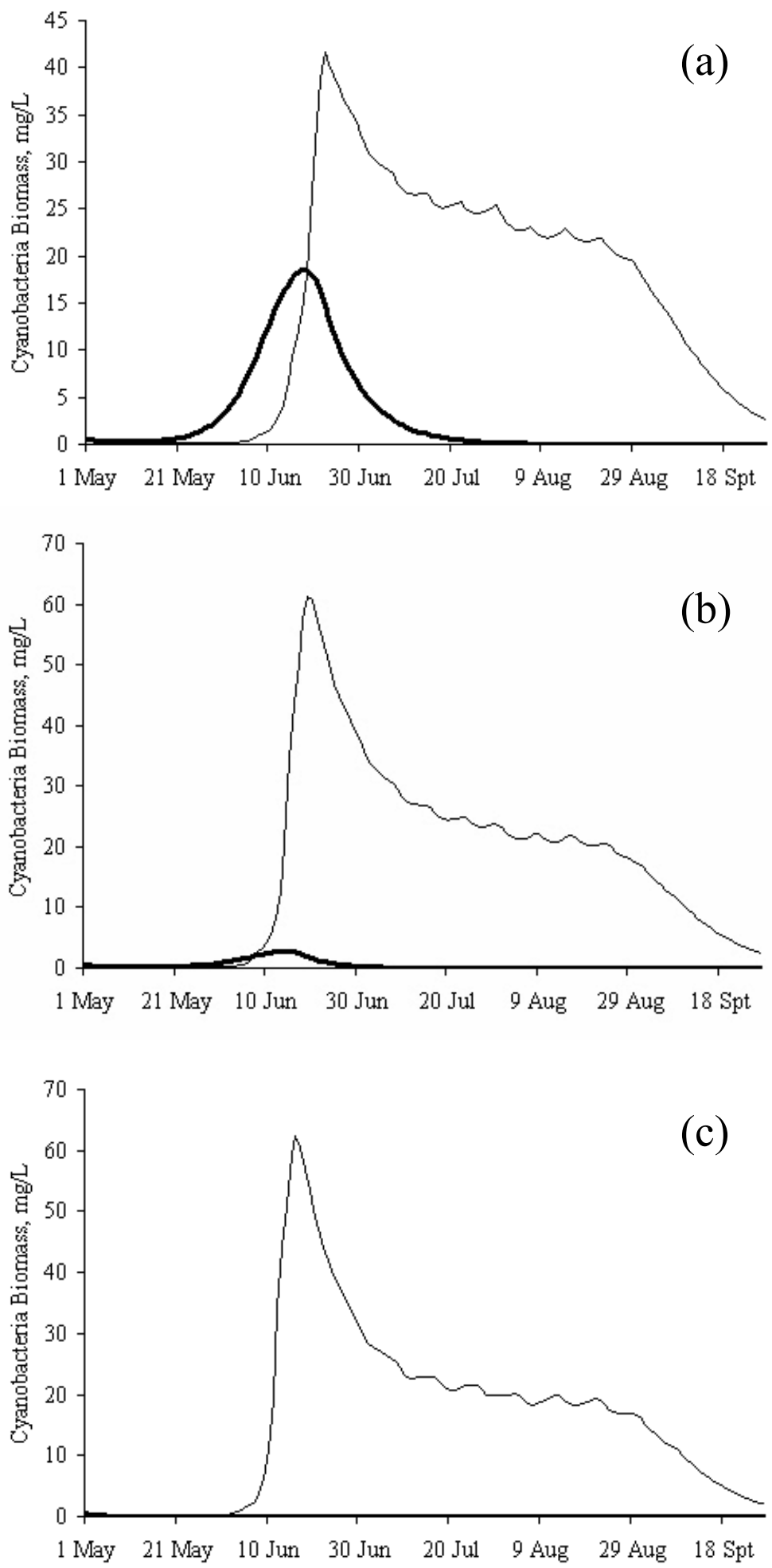

Fig. 2. Model calculations of biomass of cyanobacteria: the thick line - Anabaena flos-aquae, the thin line Microcystis aeruginosa. Biomass of silver carp is: (a) 10, (b) 20 , (c) $50 \mathrm{~g} \cdot \mathrm{m}^{-3}$ 

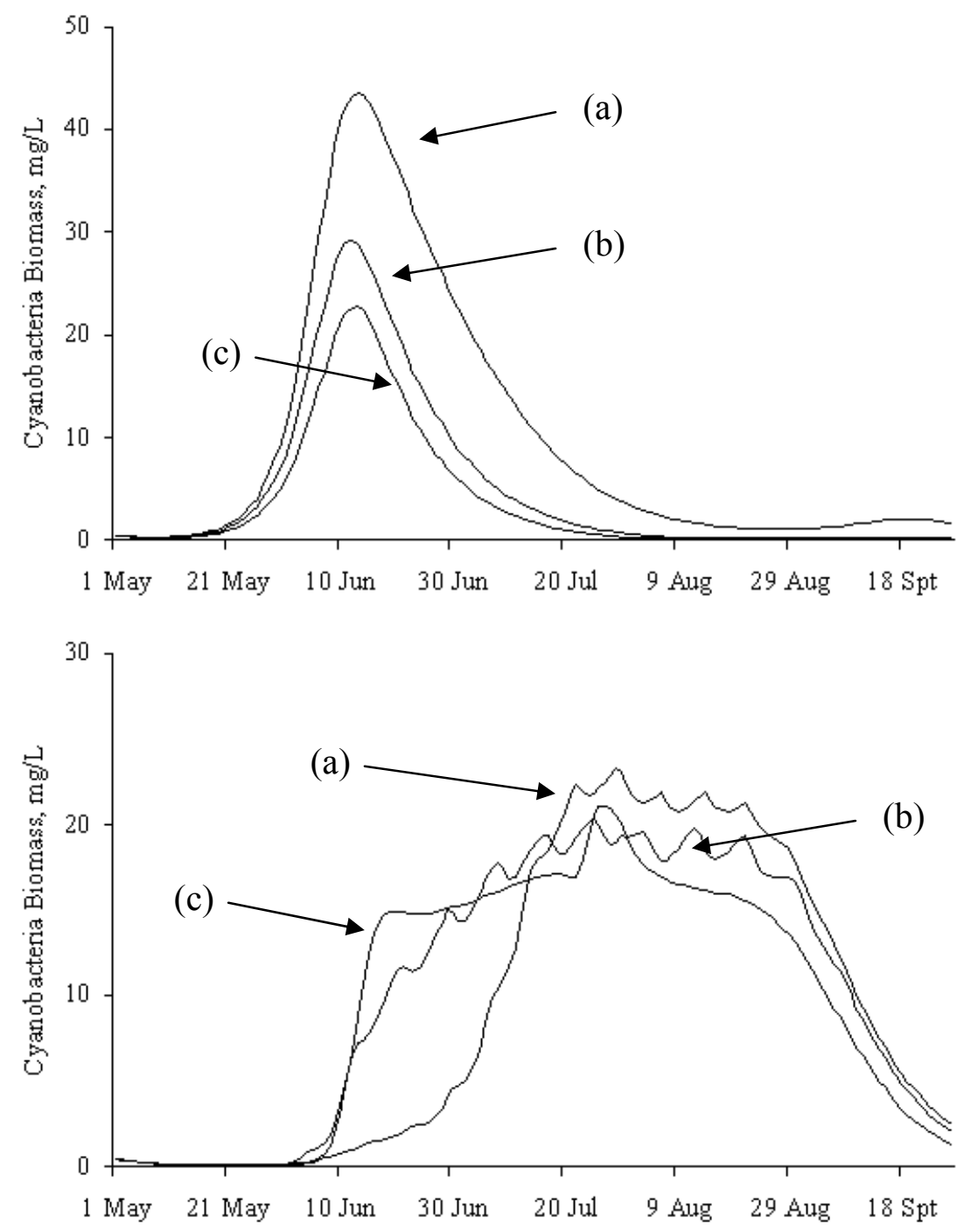

Fig. 3. Model calculations of biomass of cyanobacteria: the top panel-Anabaena flos-aquae, the bottom panel Microcystis aeruginosa. Biomass of silver carp is: (a) 10, (b) 50, (c) $100 \mathrm{~g} \cdot \mathrm{m}^{-3}$. Coefficient of assimilation Anabaena flos-aquae by silver carp is $u^{l}=0.05$

after passing through the silver carp gut. This may be one of the reasons for water blooming by these cyanobacteria when stocking reservoirs with silver carp.

The calculations made (Fig. 4), where we didn't suppose Microcystis aeruginosa to increase the growth rate after passing through silver carp gut (that is, $k^{2}=1$, see eq. 10, Table 1 ), have shown that the peak of water blooming by this species of cyanobacteria shifts to later periods and the width of the peak decreases as compared to the results given in Fig. 2.
More impressive is the calculation which assumes Anabaena flos-aquae to be weakly assimilated by silver carp $\left(u^{l}=0.05\right)$, and growth rate of the species Microcystis aeruginosa not to be stimulated after passing through fish gut $\left(k^{2} 1\right)$. In this case, the width of water blooming peak by Microcystis aeruginosa (Fig. 5), is two times less than in the calculations presented in Fig. 3. Such changes reveal that the growth stimulation of Microcystis aeruginosa cyanobacteria after passing through fish gut $\left(k^{2}=3\right)$ may be 

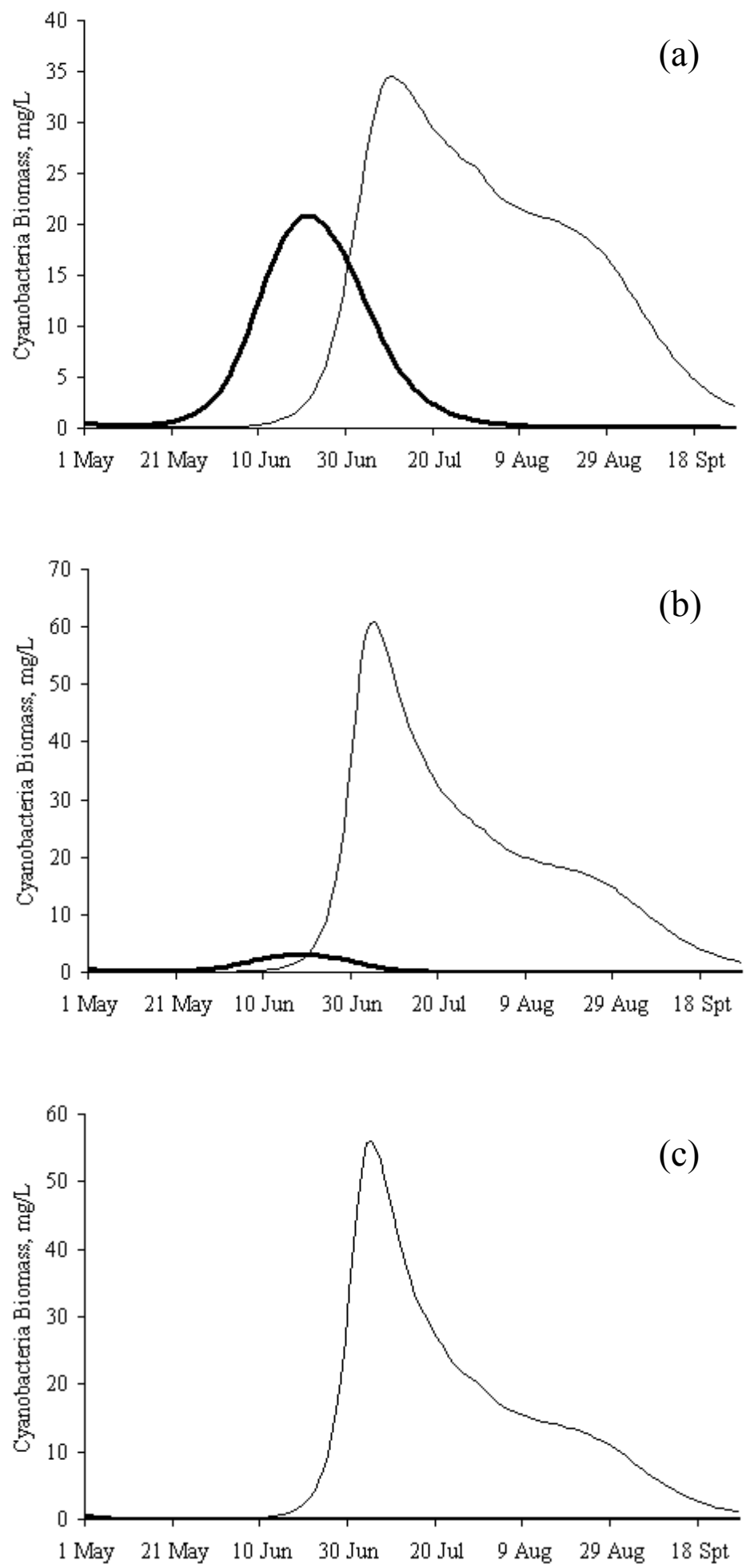

Fig. 4. Model calculations of biomass of cyanobacteria: the thick line - Anabaena flos-aquae, the thin line Microcystis aeruginosa. Biomass of silver carp is: (a) 10, (b) 20, (c) $50 \mathrm{~g} \cdot \mathrm{m}^{-3}$. Coefficient $k^{2}=1$ 

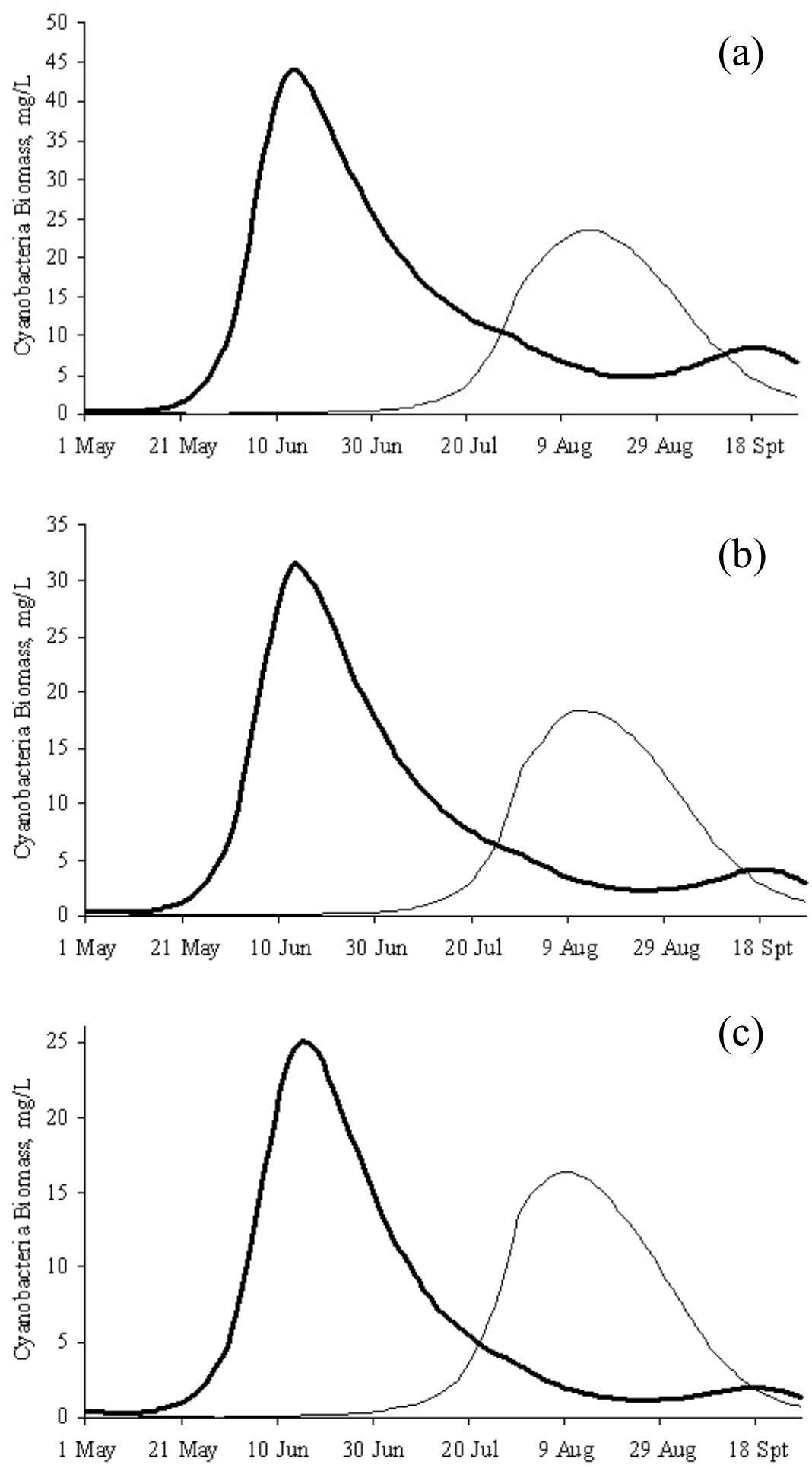

Fig. 5. Model calculations of biomass of cyanobacteria: the thick line - Anabaena flos-aquae, the thin line Microcystis aeruginosa. Biomass of silver carp is: (a) 10, (b) 50, (c) $100 \mathrm{~g} \cdot \mathrm{m}^{-3}$. Coefficient of assimilation Anabaena flos-aquae by silver carp $u^{l}=0.05$. Coefficient $k^{2}=1$ 
an important factor of maintaining reservoir blooming by this species of cyanobacteria.

Thus, the cyanobacteria species simulated reveal an opposite response to reservoirs stocking with silver carp. Minimal reservoir stocking may result in a significant decrease of Anabaena flosaquae biomass (Fig. 2a). The development of Microcystis aeruginosa is not, in fact, controlled by silver carp. Increasing stocking may result in an undesirable effect - forming blooming outbreaks by Microcystis aeruginosa (Fig. 2b,c; Fig. 4b,c).

The simulation results have a qualitative character because the model is based on abstract but admissible values of parameters and data on water temperature, surface irradiation and phosphorous loading. The results couldn't be considered to be a precise forecast for any aquatic ecosystem. However, such calculations can explain why the efficiency of using silver carp in water management may differ significantly from case to case.

\section{Conclusions}

This work presents a model describing the biomass dynamics of two typical species of cyanobacteria - Anabaena flos-aquae and Microcystis aeruginosa. This model differs from all the previous phytoplankton models by allowing for direct influence of silver carp on cyanobacterial growth. As far as is known, there is no models taking into account the stimulation of cyanobacteria growth rate and digestion by silver carp simultaneously.

The results obtained have shown that reservoir stocking with silver carp inhibits the development of Anabaena flos-aquae. Even if one assumes this species of cyanobacteria to be weakly assimilated by silver carp, it is possible to decrease significantly the peak of biomass value. It can be assumed that cyanobacteria species, whose growth is not stimulated after passing through fish gut, won't be able to form water blooming when controlled by silver carp.

The species Microcystis aeruginosa shows an opposite response to reservoir stocking with silver carp. One of the reasons for maintaining blooming may be its passing through fish gut and its weak assimilation by silver carp. It is not efficient to use silver carp to control water blooming outbreaks by Microcystis aeruginosa even at high levels of stocking. In this case, it is necessary to apply other methods to control rapid development of cyanobacteria.

Therefore, the success of biomanipulations using silver carp depends on what species of cyanobacteria dominates the ecosystem during water blooming period. When planning biomanipulations using silver carp, it is necessary to take into account species-specific character of relationships between fish and cyanobacteria.

\section{Acknowledgements}

The work was supported by the grant NWORFBR No. 047.017.012 from The Netherlands Organization for Scientific Research and Russian Foundation for Basic Research. The anonymous reviewers are kindly acknowledged for valuable suggestions, criticism and linguistic improvements.

\section{References}

Abrosov N.S., Kovrov B.G., Cherepanov O.A. (1982) Ekologicheskiye mekhanizmy sosuschestvovaniya i vidovoi regulyatsii (Ecological mechanisms of co-existence and species regulation). Nauka, Novosibirsk, 302 pp. (in Russian).

Annadotter H., Cronberg G., Aagren R., Lundstedt B., Nilsson P.-A., Strobeck S. (1999) Multiple techniques for lake restoration. Hydrobiologia. 395/396: 77-85. 
Antalfi A., Tolg T. (1971) Graskarpfen. PflanzenfressendeFische. Donau-Verlag, Giinzburg, 207 pp.

Bolsunovsky A.Ya. (1999) Ekologo-biofizicheskie mekhanizmy dominirovaniya mikrovodoroslei v kul'ture i vodoeme (Ecological biophysical mechanisms of microalgae predominance in the culture and in the reservoir). Ph.D thesis, Krasnoyarsk, 48 pp. (in Russian).

Burke J.S., Bayne D.R., Rea H. (1986) Impact of silver carp and bighead carp on plankton communities of channel catfish ponds. Aquaculture 55: 59-68.

Crisman T.L., Beaver J.R. (1990) Applicability of planktonic biomanipulation for managing eutrophication in the subtropics. Hydrobiologia 200/201: 177-185.

Dae-Young Lee, G-Yull Rhee (1999) Kinetics of growth and death in Anabaena flos-aquae (cyanobacteria) under light limitation and supersaturation. Journal of Phycology 35: 700-709.

Datta S., Jana B. (1998) Control of bloom in a tropical lake: grazing efficiency of some herbivorous fish. Journal of Fish Biology 53: 12-24.

Domaizon I., Devaux J. (1999) Impact of moderate silver carp biomass gradient on zooplankton communities in a eutrophic reservoir. Consequences for the use of silver carp in biomanipulation. Ecology, 322: 621-628.

Drenner R.W. Hambright K.D. (2002) Piscivores, trophic cascades, and lake management. The Scientific World 2: 284-307.

Fukushima M., Takamura N., Sun L., Kagawa M., Matsushige K. (1999) Changes in the plankton community following introduction of filtr-feeding planktivorous fish. Freshwater Biology 42: 719-735.

Gophen M. (1990) Biomanipulation: retrospective and future development. Hydrobiologia 200/201: 1-11.

Gubanov V.G., Degermendzhy A.G., Bayanova Yu.N., Bolsunovsky A.Ya., Gladyshev M.I., Gribovskaya I.V., Zinenko G.K., Kalachova G.S., Stepen A.A., Temerova T.A., Ustyugova T.T., Khromechek E.B., Shitova L.Yu. (1996) Forecast Simulation of Ecosystem Dynamics and Water Quality Based on Kinetic Characteristics. Contemporary Problems of Ecology 3 (5): 453-472 (in Russian).

Gulati R.D., van Donk E. (2002) Lakes in the Netherlands, their origin, eutrophication and restoration: state-of-the-art review. Hydrobiologia 478: 73-106.

Herodek S., Tatrai I., Olah J., Vörös L. (1989) Feeding experiments with silver carp (Hypophthalmichthys molitrix Val.) fry. Aquaculture 83: 331-344.

Kolmakov V.I., Gladyshev M.I., Kravchuk E.S., Chuprov S.M., Anishchenko O.V., Ivanova E.A., Trusova M.Yu. (2006) Species-specific stimulation of cyanobacteria by silver carp Hypophthalmichthys molitrix (Val.). Doklady Biological Sciences 408(1): 223-225.

Lammens E.H. (1999) The central role of fish in lake restoration and management. Hydrobiologia 395/396: 191-198.

Miura T. (1990) Effects of planktivorous fishes on the plankton community in a eutrophic lake. Hydrobiologia 200/ 201: 567-579.

Montealegre R.J., Verreth J., Streenbergen K., Moed J., Machiels M. (1995) A dynamic simulation model for the blooming of Oscillatoria agardhii in a monomictic lake. Ecological Modelling 78: 17-24.

Omlin M., Reichert P., Forster R. (2001) Biogeochemical model of Lake Zürich: model equations and results. Ecological Modelling 141: 77-103. 
Opuszynski K., Shireman J.V., Cichra C.E. (1991) Food assimilation and filtering rate of bighead carp kept in cages. Hydrobiologia 220: 49-56.

Ping Xie, Jiankang Liu (2001) Practical success of biomanipulation using filter-feeding fish to control cyanobacteria blooms. The Scientiffic World 1: 337-356.

Prokopkin I.G., Gubanov V.G., Gladyshev M.I. (2006) Modelling the effect of planktivorous fish removal in a reservoir on the biomass of cyanobacteria. Ecological Modelling 190 (3-4): 419-431.

Radke R.J., Kahl U. (2002) Effect of filter-feeding fish (silver carp, Hypophthalmichthys molitrix) on phyto- and zooplankton in a mesotrophic reservoir: result from an enclosure experiment. Freshwater Biology 47: 2337-2344.

Robarts R.D., Zohary T. (1987) Temperature effects on photosynthetic capacity, respiration, and growth rates of bloom-forming cyanobacteria. New Zealand Journal of Marine and Freshwater Research 21: 391-399.

Spittler P. (1981) Zur Bestimmung der Filtrierraten vorge-streckter Silberkarpfen (Hypophthalmichthys molitrix). Wis-senschaftliche Zeitschrift der Wilhelm-Pieck-Univ. Rostock 30: 109-111.

Starling, F. (1993) Control of eutrophication by silver carp (Hypophthalmichthys molitrix) in the tropical Paranoa Reservoir (Brasilia, Brazil): a mesocosm experiment. Hydrobiologia 257: 143-152.

Starling F.L.R., Rocha A.J.A. (1990) Experimental study of the impacts of planktivorous fishes on plankton community and eutrophication of a tropical Brazilian reservoir. Hydrobiologia 200/201: 581-591.

\title{
Теоретический анализ потенциала толстолобика
}

\section{Hypophthalmichthys molitrix для контроля цветения воды, вызываемого разными видами цианобактерий}

\author{
И.Г. Прокопкина \\ В.Г. Губанов ${ }^{\text {, М.И. Гладышев }}{ }^{\text {, }}$ \\ ${ }^{a}$ Институт биофизики Сибирского отделения Российской академии наук \\ Россия 660036, Красноярск, Академгородок \\ ${ }^{b}$ Сибирский федеральный университет \\ Россия 660041, Красноярск, пр. Свободный, 79
}

В работе проводится теоретический анализ возможности белого толстолобика (Hypophthalmichthys molitrix) контролировать «иветение» водоемов некоторыми видами цианобактерий. Для решения этой задачи построена имитачионная модель, описывающая сообщество ичианобактерий в абстрактном водоеме. В качестве моделируемых видов выбраны Anabaenaflos-aquaе и Microcystis aeruginosa. Модельныерасчеты показывают, что интродукиия рыб в водоем подавляет развитие Anabaena flos-аqиае. «Цветение» воды, формируемое Microcystis aeruginosa, наоборот не сдерживается бельм толстолобиком. Одной из причин такой реакиии Microcystis aeruginosa на зарыбление водоема белым толстолобиком может быть стимулячия роста этого вида после прохождения через кишечник рыб.Таким образом, возможность белого толстолобика контролировать рост цианобактерий в масштабах 
Igor G.Prokopkin, Vladimir I. Kolmakov... Theoretical Analysis of the Potential of Silver Carp...

целого водоема носит видоспецичфичный характер, который необходимо учитьвать при планировании мероприятий по ликвидацчии «цуветений».

Ключевые слова: имитационная модель, биоманипуляциия, толстолобик, цуианобактерии 